\title{
Crustacean community composition and trophic use of the drift vegetation habitat by juvenile splitnose rockfish Sebastes diploproa
}

\author{
J. Anne Shaffer*, Daniel C. Doty, Raymond M. Buckley, James E. West \\ Washington State Department of Fish \& Wildlife, Marine Resources Division, 600 Capitol Way North, Olympia, \\ Washington 98501-1091, USA
}

\begin{abstract}
The community composition and trophic use of the drift vegetation habitat by pre-settlement juvenile splitnose rockfish Sebastes diploproa was documented in June, August, and October 1992 in the San Juan Archipelago, Washington, USA. Fucus spp., Zostera spp. and Nereocystis luetkeana were the dominant vegetation for the months sampled. Juvenile $S$. diploproa collected from the drift vegetation habitat fed mainly on planktonic organisms, including copepods and cladocerans, during June and August. In October, diets shifted to larger epiphytic prey and were dominated by 1 amphipod species. Of 5 major prey taxa, 3 had significantly different densities in drift vegetation and nearby open water habitats. Prey taxa were not dominant in the drift vegetation habitat in June and August, indicating a high degree of prey selection during these months. In October, dominant prey taxa made up a large proportion of the crustacean community in the drift vegetation habitat and less prey selection occurred. Community indices of the drift vegetation habitat were up to twice as high as those of the adjacent open water habitat for the 3 mo sampled due to vegetation associated crustaceans. Drift vegetation provides nearshore habitat features to pelagic systems. It provides food, refuge, and possibly transport from offshore to nearshore habitats for a number of recreationally and commercially important species.
\end{abstract}

KEY WORDS: Drift vegetation - Algae - Sebastes diploproa Crustacean - San Juan Archipelago Plankton - Nearshore $\cdot$ Fucus sp. - Nereocystis luetkeana - Zostera marina

\section{INTRODUCTION}

Vegetated nearshore estuarine and marine habitats consist of dynamic and complex intertidal and shallow subtidal communities (Foster \& Schiel 1985, Hicks 1986). A number of fish species depend on these habitats for refuge and food resources and have developed complex life history stages to utilize seasonally available refuge and resources (Carr 1989, Love et al. 1991). Floating mats of detached intertidal and subtidal vegetation, called drift vegetation, are formed in tide-, wind-, and ocean-current-driven convergent zones. They have relatively high densities of planktonic organisms (Franks 1992) and create a unique habitat that offers components of nearshore vegetated habitats

\footnotetext{
- Present address: PO Box 2263, Port Angeles, Washington 98362, USA
}

to open water pelagic systems (Gorlova \& Fedoryako 1986). This nearshore and pelagic mix produces a dynamic, rich resource providing refuge and fooc for many marine organisms, including numerous commercially important fishes and invertebrates (Mitchell \& Hunter 1970, Heck \& Thoman 1981, Kulczycki et al. 1981, Lenanton 1982, Robertson \& Lenanton 1984, Kingsford \& Choat 1985, Gorelova \& Fedoryako 1986, Lenanton \& Caputi 1989, Wright 1989, Sogard \& Able 1991, Kingsford 1992).

Drift vegetation mats are very mobile, with direction dictated by wind and current (Harrold \& Lisin 1989). Net transport of these drift habitats is onshore (Shanks 1988, Harrold \& Lisin 1989). Drift vegetation may stay buoyant for days (Harrold \& Lisin 1989). However, once negatively buoyant, the material making up the drift habitat may sink within $40 \mathrm{~h}$ (Johnson \& Richardson 1977). Increased wind and surface water disturbance largely determine the sinking process of drift 
vegetation (Johnson \& Richardson 1977). Drift vegetation may therefore also act as a unique transportation system of nutrients, larvae, juvenile fish, and pollutants from surface pelagic to nearshore and benthic habitats (Johnson \& Richardson 1977, Kulczycki et al. 1981. Kingsford \& Choat 1985, Shanks 1988, Kingsford 1992).

While use of the drift vegetation habitat by juvenile fishes has been repeatedly documented, refuge and trophic components have not been studied simultaneously. Studies addressing refuge and trophic interactions in drift vegetation habitats have, to date, included visual observations (Mitchell \& Hunter 1970), analysis of gut contents of fish in this habitat (Robertson \& Lenanton 1984, Wright 1984, Gorlova \& Fedoryako 1986), and inference of prey presence and use (Kulczycki et al. 1981, Lenanton 1982, Kingsford \& Choat 1985, Kingsford 1992). Heck \& Thoman (1981) attempted to investigate the relationship between juvenile fish, prey consumption, and habitat selection, but did not address community composition of the drift vegetation habitat or correlate prey availability with preferential use.
Our study investigated the function of the drift vegetation habitat for juvenile splitnose rockfish Sebastes diploproa in the San Juan Archipelago, northern Puget Sound, Washington, USA. The goals of this study were to (1) document the trophic function of the drift vegetation habitat, including prey selection by comparing prey availability and use, (2) compare splitnose rockfish prey densities in drift and adjacent open water habitats, and (3) define the crustacean communities of the drift vegetation and adjacent open water habitats.

\section{MATERIALS AND METHODS}

The drift vegetation habitat of the San Juan Archipelago (Fig. 1) was sampled in June, August, and October 1992. Once each month, during daylight hours, splitnose rockfish were collected from a minimum of 2 natural drift lines of an approximately $20 \mathrm{~km}^{2}$ area in Upright Channel and Rosario Strait. Individual lines of drift vegetation varied from approximately $6 \mathrm{~m}^{2}$ to $30 \mathrm{~m}^{2}$. All were approximately $31.75 \mathrm{~cm}$ thick. Juvenile splitnose rockfish were collected with hand-

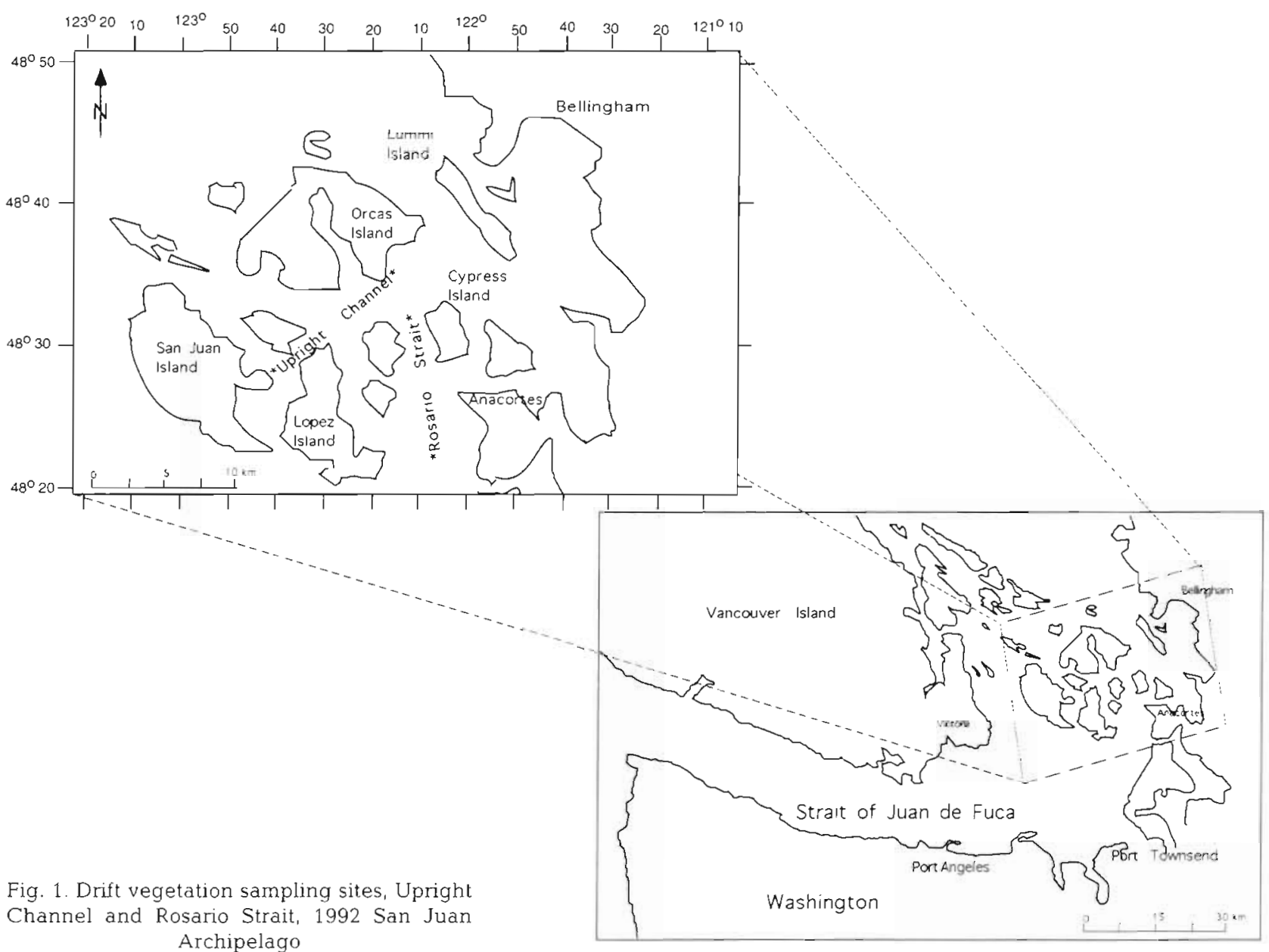


held, $3 \mathrm{~mm}$ mesh dipnets, relaxed in MS 222, and preserved in $5 \%$ buffered formalin for later stomach analysis. In the drift vegetation habitat where juvenile rockfish were present, neuston and epiphyte communities were sampled using $12 \mathrm{~cm}$ diameter, $130 \mu \mathrm{m}$ mesh, hand-held dipnets, which were submerged $31 \mathrm{~cm}$ below sea surface and then pulled vertically through the water and drift vegetation. All contents, including vegetation, were immediately preserved in $5 \%$ buffered formalin. Open water samples were collected using the same technique from areas with no visible drift vegetation within $0.40 \mathrm{~km}$ of a sampled drift area. A minimum of 20 fish (10 per drift line) were collected per sampling date. Five drift vegetation and 5 open water samples were taken per sampling date. Within each month, all samples were collected within a 2 h period.

In the laboratory, fish were identified using meristic characters (including standard dorsal and pectoral fin ray counts), and a random subsample of 20 fish were measured, their stomachs visually assessed for fullness, extracted, and wet weighed. Prey were then extracted, visually assessed for state of digestion, and identified to lowest possible taxon. Taxa were then counted and wet weighed. Data were analyzed for numerical and gravimetric composition including density, percent composition, taxa richness (number of taxa), Shannon-Wiener diversity, evenness, and dominance by the FORTRAN computer program GUTBUGS (Simenstad et al. 1980).

For numerical diversity $H^{\prime}$ (Shannon-Wiener: see Pielou 1975):

$$
H^{\prime}=\sum N \log N
$$

where $N \log N=-N \log N$ and

$N \log N=$

$N \log N+\left[\frac{\text { Occurrence }}{100} \times \frac{1}{\log _{10}(2)} \times \log _{10}\left(\frac{\text { Occurrence }}{100}\right)\right]$

Occurrence $=$

$$
100 \times \frac{\text { Number of prey } I}{\text { Total of identified and unidentified prey }}
$$

Evenness $(J)$ and dominance were calculated as described in Zar (1984):

$$
J=\frac{H}{\log k}
$$

where $k=$ number of taxa; and

$$
\text { Dominance }=1-J
$$

A total of 5 drift vegetation and 5 open water samples were rinsed over a $130 \mu \mathrm{m}$ screen. Vegetation were sorted to major taxa, estimated for volume by water displacement, dried to constant weight at $80^{\circ} \mathrm{C}$ and weighed to the nearest $0.01 \mathrm{~g}$ for each taxon. Algal volume and biomass were calculated per cubic meter volume of water for each sample and averaged for each date. Crustaceans in each sample were sorted, identified to lowest taxa, counted, and weighed. Numerical and gravimetric composition and community analysis including Shannon-Wiener diversity, dominance, evenness and taxa richness were calculated with the FORTRAN computer program SUPERPLANKTON (Simenstad et al. 1980) using the algorithms described above. Abundance data of dominant prey taxa in open water and drift vegetation habitats showed a high variance to mean ratio and, therefore, were log transformed and homogeneity of variances was tested. $H_{0}$ was accepted for all comparisons $\left(F_{0.05,(2) 4,4}=9.60\right)$. Log transformed data were then tested for significant differences using single factor ANOVA (Microsoft EXCEL 5.1).

Prey selection was defined with standard foraging ratios (SFRs) as defined in Manly et al. (1972):

$$
\mathrm{SFR}=\frac{P_{i} / R_{i}}{\sum P_{i} / R_{i}}
$$

where $P_{1}=\%$ abundance of prey taxa in diet, and $R_{i}=$ $\%$ abundance of prey taxa (relative to all prey taxa). SFR $<0.50$ indicates negative selection; SFR $>0.50$ indicates positive selection.

\section{RESULTS}

Fucus sp. was the dominant vegetation in drift vegetation samples taken for all months. Wood debris, eelgrass Zostera sp., and bull kelp Nereocystis luetkeana were also present. Total vegetation weight and volume were highest in August (4500 $\left.\mathrm{g} \mathrm{m}^{-3}, 47 \mathrm{l} \mathrm{m}^{-3}\right)$, followed by June $\left(1750 \mathrm{~g} \mathrm{~m}^{-3}, 16.75 \mathrm{I} \mathrm{m}^{-3)}\right.$, and October $(1100 \mathrm{~g}$ $\mathrm{m}^{-3}, 201 \mathrm{~m}^{-3}$ ) (Fig. 2 ).

The size of splitnose rockfish increased over the 3 sampling periods. Average total fish length was $21.3 \mathrm{~mm}(\mathrm{SD}=5.26, \mathrm{n}=20)$ in June, $27.4 \mathrm{~mm}(\mathrm{SD}=$ $6.33, \mathrm{n}=20)$ in August, and $31.1 \mathrm{~mm}(\mathrm{SD}=4.41, \mathrm{n}=20)$ in October.

\section{Stomachs}

Stomach fullness and digestion were similar for the 3 sampling dates. The average number of taxa per stomach varied with month, and content to body weight ratio decreased with each month. Stomach content diversities and evenness were relatively low for each month. Percent dominance for numerical composition fluctuated by month (Table 1). Gravimetric and numeric analysis revealed the same dominant prey 


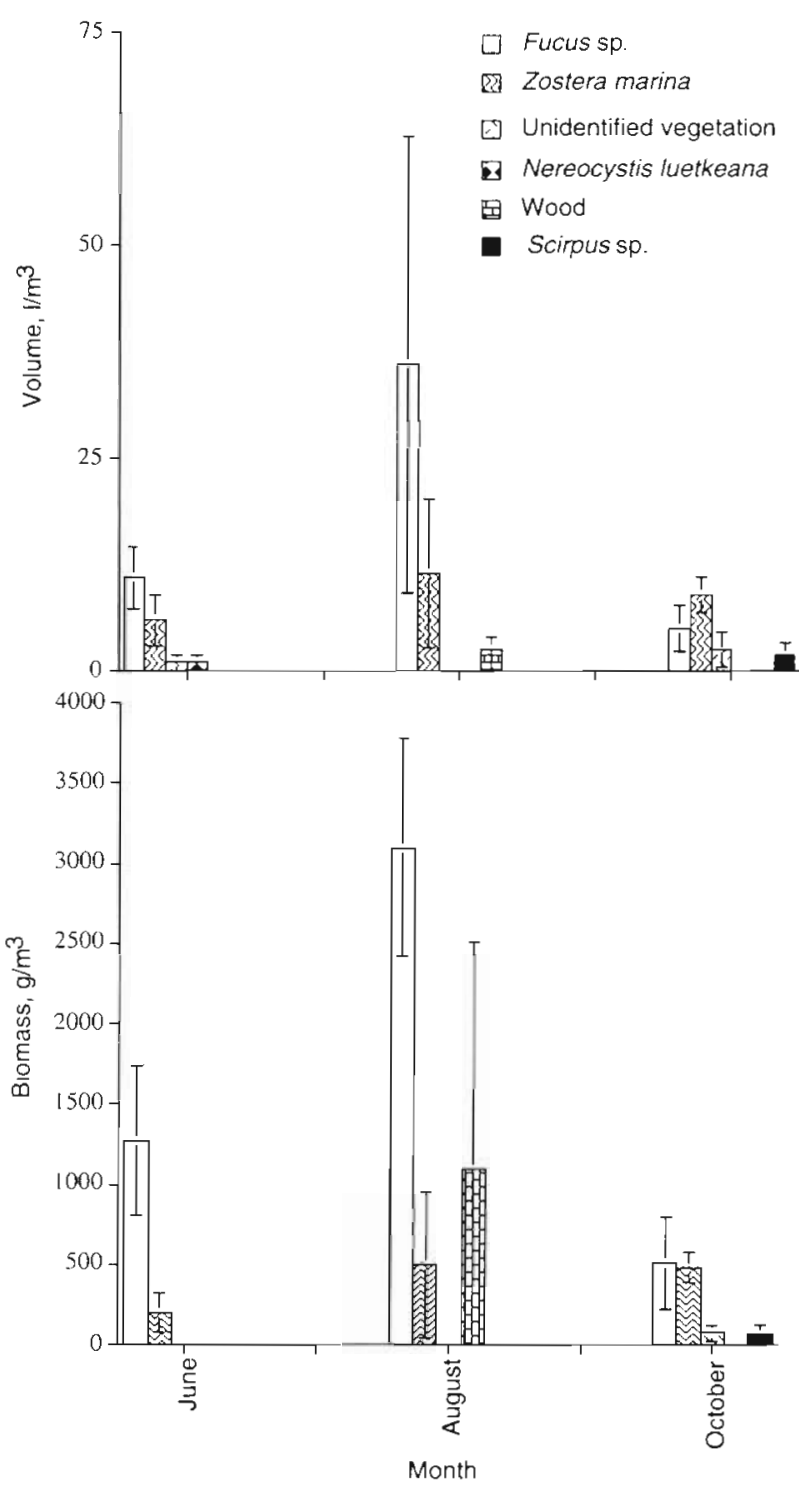

Fig. 2. Average dry weight and wet volume composition (with standard error) of drift vegetation samples collected from the San Juan Archipelago, 1992

taxa (Fig. 3). Planktonic calanoid copepods Centropages sp., Paracalanus sp., other calanoids, copepod nauplii, the cladocerans Evadne and Podon spp., and the epiphytic amphipod Calliopius sp. were dominant prey over 3 mo (Table 2). In June and August Sebastes diploproa diets were comprised almost exclusively of planktonic calanoid copepods dominated by Centropages $\mathrm{sp}$. $(80 \%$ of the percent abundance of prey in June) and copepod nauplii $(70 \%$ of total prey in August). Other planktonic organisms, including Evadne and Podon spp. and Paracalanus sp., made up the rest of the prey items for these months. Calliopius sp., an epiphytic amphipod, was the dominant prey organism in October ( $80 \%$ of the total prey consumed).
Table 1. Summary of stomach content analysis of juvenile splitnose rockfish Sebastes diploproa collected from the drift vegetation habitat of the San Juan Archipelago, Washington, USA, 1992. Fullness: $1=$ empty, $4=50 \%$ full, $7=$ distended. Digestion: $1=0 \%$ identifiable, $4=50$ to $75 \%$ identifiable, $6=$ $100 \%$ identifiable

\begin{tabular}{|lccc|}
\hline Indices & June & August & October \\
\hline Fullness & 5.00 & 5.25 & 5.75 \\
Digestion & 5.5 & 4.9 & 6.0 \\
Content weight: total weight & 3.2 & 2.6 & 2.0 \\
Diversity & 1.8 & 1.7 & 1.0 \\
Evenness & 0.36 & 0.49 & 0.28 \\
Percent dominance & 0.64 & 0.51 & 0.72 \\
Taxa richness & 15 & 19 & 11 \\
\hline
\end{tabular}

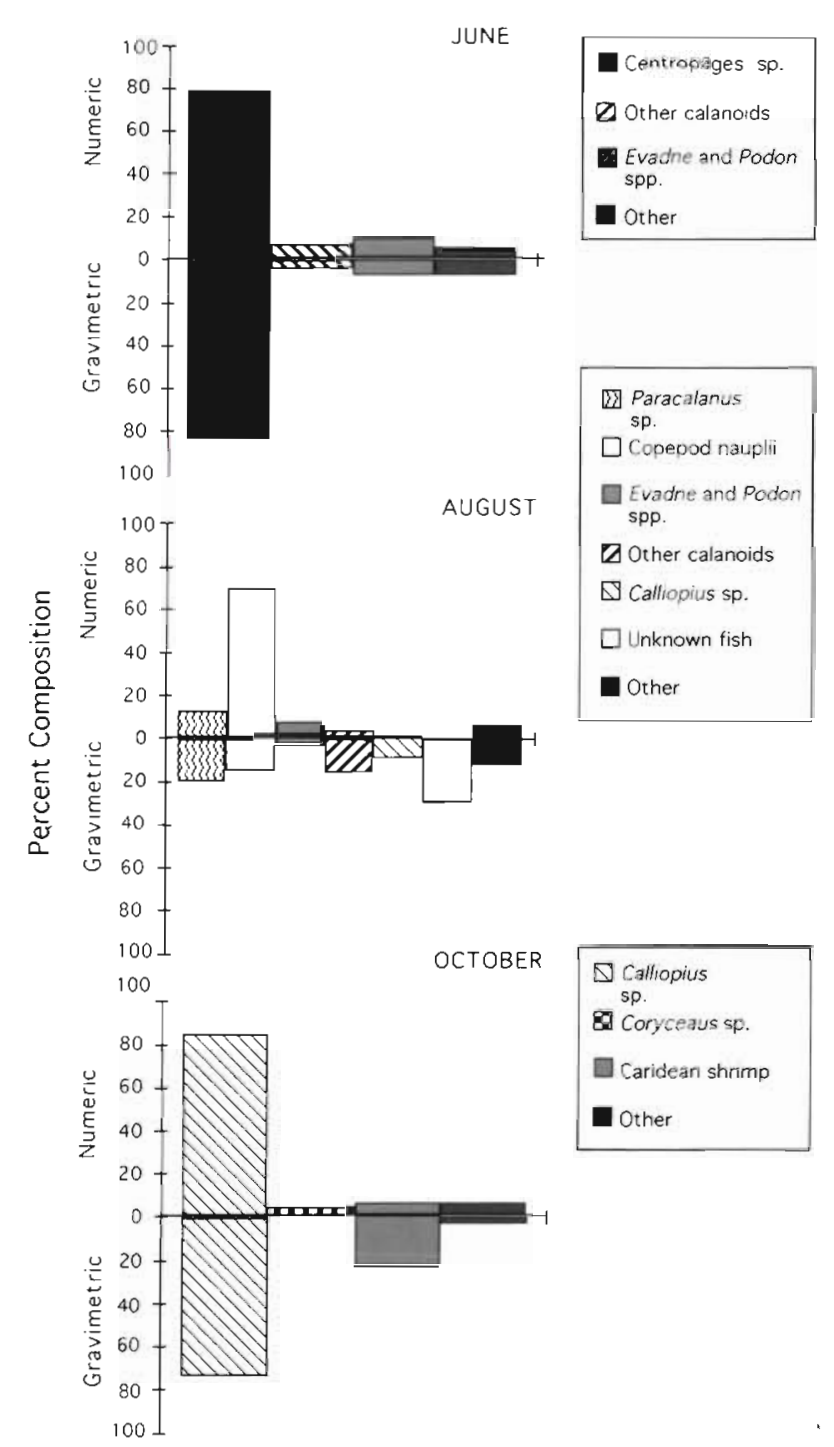

Fig. 3. Numeric and gravinetric prey composition of stomachs of juvenile splitnose rockfish Sebastes diploproa collected from the drift vegetation habitat of the San Juan Archipelago, 1992 
Table 2. Species list and percent total prey abundance found in stomachs of juvenile splitnose rockfish Sebastes diploproa collected from the San Juan Archipelago drift vegetation habitat, $1992 . \cdot 0.001$ to $5 \%, \cdots 5.1$ to $30 \%, \cdots 60.1$ to $100 \%$

\begin{tabular}{|c|c|c|c|}
\hline Species & June & August & October \\
\hline Bivalvia & & . & \\
\hline Evadne and Podon spp. & *. & .. & \\
\hline Ostrocoda & & - & \\
\hline Copepoda nauplii & & $\cdots$ & \\
\hline Calanoida & .. & - & \\
\hline Calanus sp. & - & . & - \\
\hline Paracalanus sp. & - & $\cdots$ & . \\
\hline Pseudocalanus sp. & - & . & - \\
\hline Microcalanus sp. & - & & \\
\hline Centropages sp. & $\cdots$ & . & . \\
\hline Acartia sp. & • & * & \\
\hline Cyclopoid & . & & \\
\hline Harpacticoida, unid. & & * & \\
\hline Harpacticus sp. & & * & \\
\hline Dactylopodia sp. & & . & \\
\hline Corycaeus sp. & . & - & - \\
\hline Oithona sp. & & & . \\
\hline Balanomorpha & & . & - \\
\hline Gammarid amphipods & . & - & \\
\hline Calliopius sp. & & . & .... \\
\hline Hyale sp. & & & • \\
\hline Hyperiidae & - & & \\
\hline Decapoda & . & & \\
\hline Caridean shrimp & & & .. \\
\hline Osteichthyes & & . & \\
\hline
\end{tabular}

\section{Plankton}

Total number of organisms was higher in drift vegetation than in open water habitat during all 3 mo. The drift vegetation habitat had significantly higher numbers in June and October $\left[143810\right.$ vs $13611, p_{(0.05) 1,8}=$ 0.0059 ; and 117916 vs $11417, \mathrm{p}_{(0.05) 1,8}=0.0008$, respectively]. August abundances were not significantly different between drift vegetation and open water (262916 vs $\left.90083, \mathrm{p}_{(0.05) 1,8}=0.34\right)$. Diversity and taxa richness of drift vegetation were markedly higher than open water samples for all 3 mo analyzed (Table 3). Taxa richness differences were in part due to the large

Table 3. Species diversity and richness for drift vegetation and open water habitats of the San Juan Archipelago, 1992

\begin{tabular}{|c|c|c|c|c|c|c|}
\hline \multirow[t]{2}{*}{ Indices } & \multicolumn{2}{|c|}{ June } & \multicolumn{2}{|c|}{ August } & \multicolumn{2}{|c|}{ October } \\
\hline & $\begin{array}{c}\text { Drift } \\
\text { veget. }\end{array}$ & $\begin{array}{l}\text { Open } \\
\text { water }\end{array}$ & $\begin{array}{c}\text { Drift } \\
\text { veget. }\end{array}$ & $\begin{array}{l}\text { Open } \\
\text { water }\end{array}$ & $\begin{array}{c}\text { Drift } \\
\text { veget. }\end{array}$ & $\begin{array}{l}\text { Open } \\
\text { water }\end{array}$ \\
\hline Diversity & 3.2 & 1.6 & 1.8 & 0.8 & 1.7 & 1.3 \\
\hline Richness: & & & & & & \\
\hline Epiphytic & 18 & 2 & 17 & 7 & 12 & 2 \\
\hline Planktonic & 25 & 8 & 20 & 11 & 7 & 8 \\
\hline Total & 43 & 10 & 37 & 18 & 19 & 10 \\
\hline
\end{tabular}

contribution of epiphytic organisms which made up roughly half of the total number of taxa for drift vegetation samples, and less than a third of open water taxa. Calliopius sp. was the dominant organism for all 3 mo. Copepod nauplii, the harpacticoid copepod Zaus sp., and other harpacticoids, were the next dominant taxa by month (Table 4).

Densities of Centropages sp. in drift vegetation and open water habitats were not significantly different in June and August $\left[\mathrm{p}_{(0,05) 1,8}=0.18\right.$ and 14]. Paracalanus $\mathrm{sp}$. density was not significantly higher in drift vegetation than in open water in August or October $\left[\mathrm{p}_{(05) 1,8}=\right.$ 0.51 and 0.34; Fig. 4]. Evadne and Podon spp. were present in significantly higher numbers in drift vegetation habitat in June $\left[p_{(0.05) 1,8}=0.0027\right]$. Densities of all other calanoid copepods combined were significantly
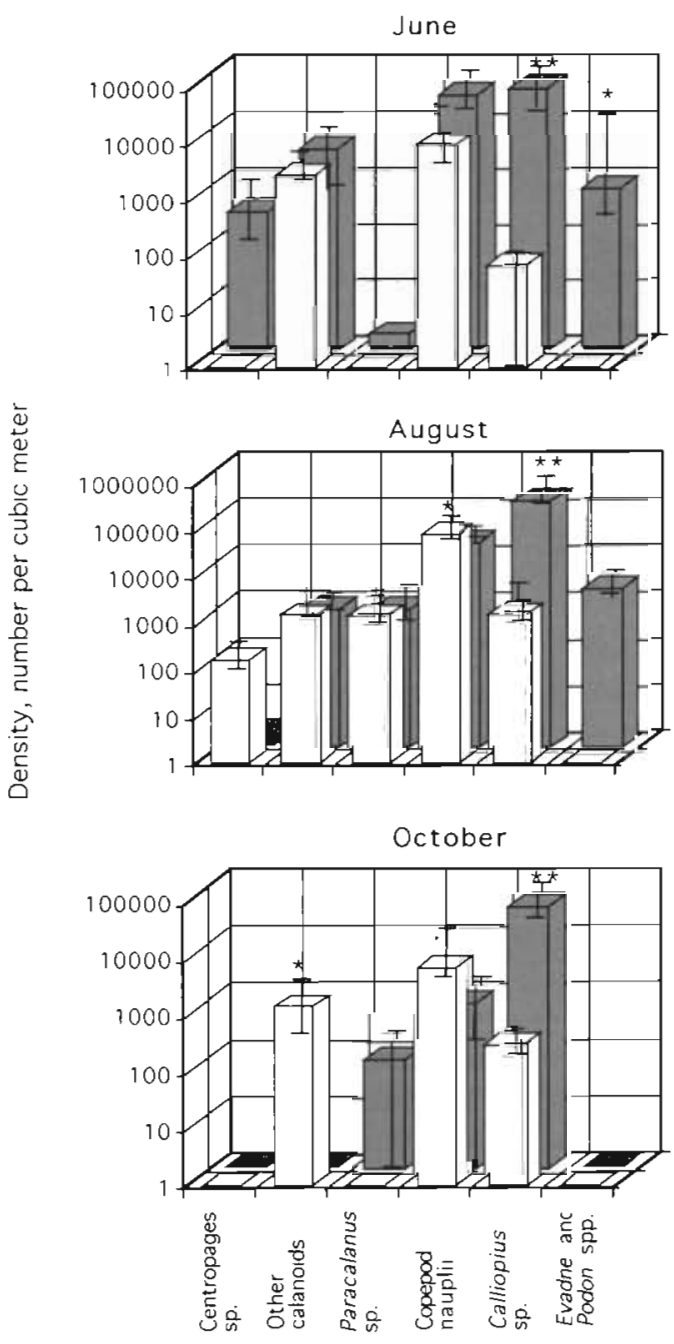

Fig. 4. Average densities and standard errors for dominant prey taxa collected from the drift vegetation ( $\square$ ) and open water ( $\square$ ) habitats of the San Juan Archipelago, 1992. Statistically significant differences are indicated: $p<0.05$; $\because p<0.01$ 
Table 4. Percent total abundance for crustaceans and molluscs collected $\cdot 0.001$ to $5 \%, \cdots 5.1$ to $30 \%, \cdots 30.1$ to $60 \%, \cdots 60.1$ to $100 \%$

\begin{tabular}{|c|c|c|c|c|c|c|}
\hline \multirow[t]{2}{*}{ Species } & \multicolumn{2}{|c|}{ June } & \multicolumn{2}{|c|}{ August } & \multicolumn{2}{|c|}{ October } \\
\hline & $\begin{array}{c}\text { Drift } \\
\text { veget. }\end{array}$ & $\begin{array}{l}\text { Open } \\
\text { water }\end{array}$ & $\begin{array}{c}\text { Drift } \\
\text { veget. }\end{array}$ & $\begin{array}{l}\text { Open } \\
\text { water }\end{array}$ & $\begin{array}{c}\text { Drift } \\
\text { veget. }\end{array}$ & $\begin{array}{l}\text { Open } \\
\text { water }\end{array}$ \\
\hline Bivalvia & $\cdots$ & - & & & & \\
\hline Mytilus edulis & $\cdot$ & & & & & \\
\hline Evadne sp. & • & & & * & & \\
\hline Podon sp. & - & & - & - & & \\
\hline Ostrocoda & & & - & & - & \\
\hline Copepoda nauplii & $*$ & $\cdots$ & - & $\cdots$ & - & $\cdots$ \\
\hline Calanoida copepods, unid. & $\cdot$ & .. & $\cdots$ & $\cdot$ & & • \\
\hline Calanus sp. & - & - & $\cdot$ & - & & \\
\hline Paracalanus sp. & & & • & $\cdot$ & $\cdot$ & \\
\hline Pseudocalanus sp. & & $\cdot$ & & & & \\
\hline Microcalanus sp. & * & & • & & & \\
\hline Aetidius sp. & & & & & & - \\
\hline Centropages sp. & • & & & • & & \\
\hline Acartia sp. & $\cdot$ & . & - & * & & \\
\hline Harpacticoida, unid. & -. & & - & $\cdot$ & $\cdot$ & \\
\hline Porcellidium sp. & & & - & & & \\
\hline Harpacticus sp. & • & & - & & & \\
\hline Zaus sp. & - & & $\cdots$ & & $\ldots$ & \\
\hline Tisbe sp. & - & & - & & $\cdot$ & - \\
\hline Laophontidae & * & & - & . & $\cdot$ & \\
\hline Laophonte sp. & - & & & & & \\
\hline Ameridae & & & • & & $\cdot$ & \\
\hline Diosaccidae & - & & $\cdot$ & - & . & \\
\hline Mesochra sp. & & & - & & & \\
\hline Thalestridae & * & & & & & \\
\hline Dactylopodia sp. & • & & . & - & . & \\
\hline Paradactylopodia sp. & $\cdot$ & & & & & \\
\hline Parathalestris sp. & - & & . & & - & \\
\hline Oncaea sp. & & & $\cdot$ & & & \\
\hline Corycaeus sp. & . & - & - & - & - & . \\
\hline Oithona sp. & - & & - & • & • & $\cdot$ \\
\hline Idotea sp. & & & & & - & \\
\hline Balanomorpha & • & - & - & - & - & - \\
\hline Gammarid amphipods & & & & - & & $\cdot$ \\
\hline Ampithodae & & & & $\cdot$ & $\cdot$ & \\
\hline Calliopius sp. & $\cdots$ & $\cdot$ & $\cdots$ & • & $\cdots$ & $\cdot$ \\
\hline Hyale sp. & & & $\cdot$ & & $\cdot$ & \\
\hline Ischyroceridae & - & & & & & \\
\hline Hyperiidae & - & & - & & & \\
\hline Pleustidae & - & & & & & \\
\hline Caprellidae & $\cdot$ & & . & & . & \\
\hline Decapoda & . & & & & & \\
\hline Pleocyemata-Caridea & - & & & & $\cdot$ & \\
\hline Decapoda-Anomura & $\cdot$ & & & & & \\
\hline Decapoda-Brachyura & - & & $\cdot$ & & & \\
\hline Insecta & • & & & & & \\
\hline Diptera & * & & . & & & \\
\hline
\end{tabular}
from drift vegetation and open water habitats, San Juan Archipelago, 1992.

Dominant prey taxa were not the numerically or gravimetrically dominant taxa in plankton during June and August (Fig. 5). Centropages sp., other calanoid copepods, and cladocerans (dominant prey in June) were each less than $5 \%$ of organisms available. Copepod nauplii and Paracalanus spp., dominant prey in August, were also less than $5 \%$ of prey available. Calliopius sp., dominant prey in October, made up $35 \%$ of prey available for that month.

Juvenile splitnose rockfish actively selected prey during all 3 mo (Table 5). Centropages and Paracalanus spp. were selected both gravimetrically and numerically in June and August, respectively. Caridean shrimp were positively selected in October. Copepod nauplii, other calanoids, cladocerans, and Calliopius sp. were not actively selected gravimetrically or numerically.

\section{DISCUSSION}

Splitnose rockfish use of the drift vegetation habitat appears to be dynamic. In June and August, small juvenile Sebastes diploproa in drift vegetation habitat fed exclusively, and in some cases selectively, on planktonic copepods and cladocerans. Densities of selected prey were not always significantly different between drift and open water habitats. In October, however, the splitnose were larger and fed primarily on, but did not actively select, Calliopius sp., a large, vegetation-associated amphipod that had significantly higher densities in, and was the dominant organism of, the drift vegetation habitat. This illustrates a shift both in prey selection by $S$. diploproa and in the habitat function of the drift vegetation system for these fish. The change in prey type, availability, and selection indicates that, during spring and summer, the drift vegetation habitat may be important as a refuge for $S$. diploproa from potential

higher in open water relative to drift vegetation in October $\left[\mathrm{p}_{(0.05) 1,8}=0.0465\right]$. Copepod nauplii densities were significantly higher in open water than in drift vegetation habitat in August only $\left[p_{(005) 1,8}=0.009\right]$. Densities of Calliopius sp. were significantly higher in drift vegetation during all 3 mo sampled $\left(p_{[0,05) 1.8}=\right.$ $0.0031,0.0014$ and 0.0030 , respectively]. predation by fish and birds, rather than as a primary prey resource. In the autumn, the drift vegetation habitat may become more important for the prey resources it offers. Similar functions of other nearshore vegetated habitats for refuge and prey availability have been documented (Mitchell \& Hunter 1970, Kulczycki et al. 1981, Lenanton 1982, Robertson \& Lenanton 1984, Kingsford 1992). 
Fig. 5. Prey available to and selected by juvenile splitnose rockfish Sebastes diploproa collected from the drift vegetation habitat of the San Juan Archipelago, 1992. Taxa presented make up a minimum of $5 \%$ of all taxa available/selected

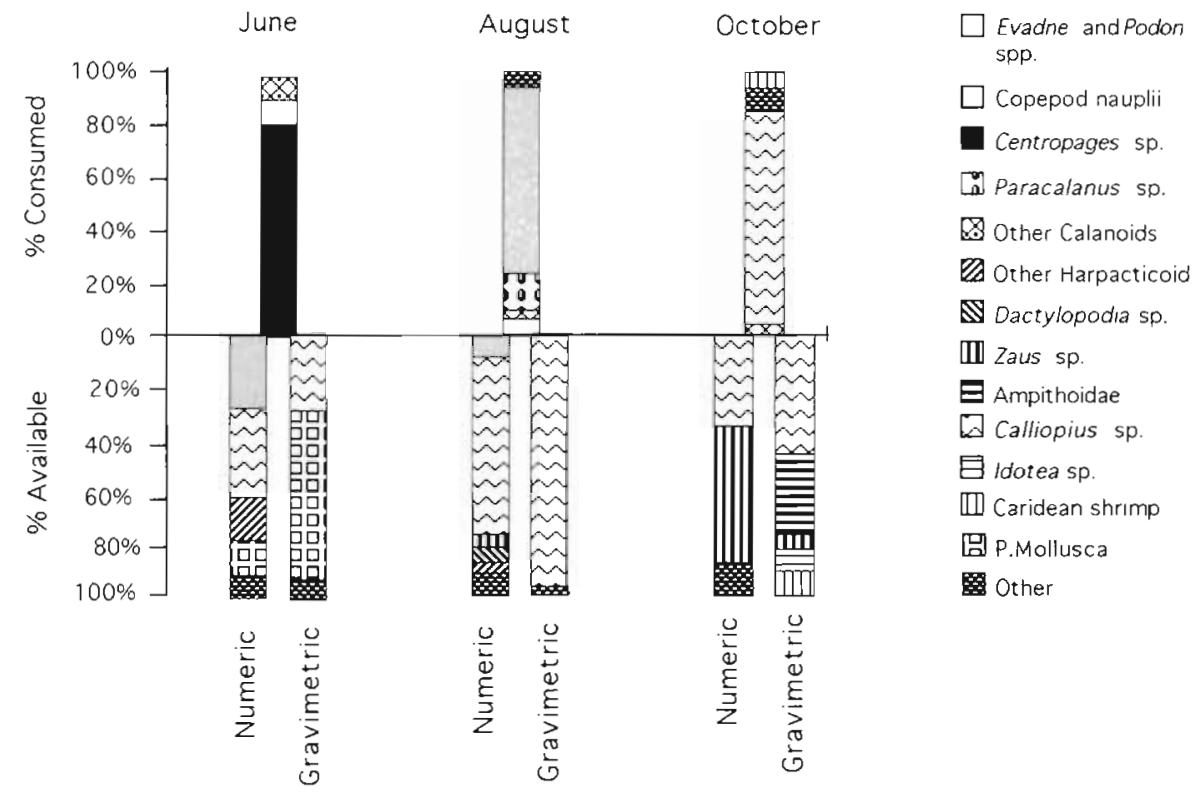

Shifts in prey from planktonic to benthic and vegetation-associated crustaceans have been well documented for juvenile rockfish and have been attributed to growth of the fish, changes in prey availability, and ontogenetic habitat shifts (Haldorson \& Richards 1986, Carr 1989, Love et al. 1991). Size increase was observed in juvenile splitnose rockfish over the 5 mo sampling period and may be a factor in the observed shifts in prey type from small planktonic prey to large epiphytic prey. Species diversity of the drift vegetation habitat was highest in June. Diets of small Sebastes diploproa during this month were not very diverse and were dominated by actively selected, small, rare

Table 5. Sebastes diploproa. Standard foraging ratios (SFR) for juvenile splitnose rockfish collected from drift vegetation habitat of the San Juan Archipelago, 1992. SFR < 0.50 indicates no selection; SFR $<0.50$ indicates active selection

\begin{tabular}{|llcc|}
\hline \multirow{2}{*}{ Month } & \multirow{2}{*}{ Species } & \multicolumn{2}{c|}{ SFR } \\
& & & \\
\hline \multirow{6}{*}{ June } & Centropages sp. & 0.89 & 0.63 \\
& Other calanoids & 0.02 & 0.02 \\
& Evadne and Podon spp. & 0.09 & 0.35 \\
& Other & 0.00 & 0.00 \\
August & Paracalanus sp. & 0.62 & 0.66 \\
& Copepod nauplii & 0.12 & 0.03 \\
& Evadne and Podon spp. & 0.11 & 0.03 \\
& Other calanoids & 0.14 & 0.27 \\
& Calliopus sp. & 0.00 & 0.00 \\
& Other & 0.01 & 0.00 \\
October & Calliopus sp. & 0.14 & 0.23 \\
& Coryceaus sp. & 0.21 & 0.21 \\
& Caridean shrimp & 0.64 & 0.55 \\
& Other & 0.01 & 0.01 \\
\hline
\end{tabular}

planktonic prey. In August, when fish were larger, the diversity of the crustacean community of the drift vegetation habitat decreased. Despite this, the diet became more diverse, and prey were fed on more evenly relative to June diets. In October, diversity of the drift vegetation community decreased again. Diets of the now larger fish also decreased in diversity and evenness and were dominated by large abundant epiphytic prey.

Prey availability may also contribute to the food shifts observed. The taxa fed on by Sebastes diploproa in June and August had much lower densities in October in both open water and drift vegetation samples. This relative decrease may have resulted in the lower number of taxa fed on in October and a shift to feeding on dominant crustaceans, such as Calliopius sp. Finally, a shift in the prey type while in the drift vegetation habitat may signal the beginning of a habitat shift from pelagic drift vegetation to benthic adult habitat. The degree to which this shift is dependent on the transport time and availability of drift vegetation habitat and the degree to which the drift vegetation habitat may drive these habitat shifts by transporting organisms to juvenile benthic habitats is unknown (Shanks 1988, Kingsford 1992).

The drift vegetation habitat is a complex and diverse habitat that offers characteristics of nearshore habitat, including vegetation and concomitant refuge and food to the pelagic system. This is best illustrated in the species diversity and richness of drift vegetation and open water samples, which are consistently higher for the drift vegetation than open water habitat. The consistently higher total number of organisms, ShannonWiener diversity, and taxa richness of the drift vegetation habitat relative to the non-drift habitat docu- 
mented in this study is consistent with other investigations and is undoubtedly due to increased habitat structure, physical processes, and plankton behavior. Johnson \& Richardson (1977) documented that upwelling at leading edges of convergent zones and Langmuir cells result in concentration of material and planktonic organisms into drift lines. Behavior of planktonic organisms may also play a role in their concentration into drift lines (Price 1988, Shanks 1988, Franks 1992).

Increased diversity of the drift vegetation habitat relative to adjacent open water habitat has been hypothesized to be the reason for the attraction of certain fish to this habitat (Robertson \& Lenanton 1984, Lenanton \& Caputi 1989, Savino \& Stein 1989).

The drift vegetation habitat may be a critical resource for a number of other fish species found in Washington coastal waters. Many of the epiphytic and planktonic taxa found in the drift habitat of this study have been documented as important prey for juveniles of commercial and sport fish of this region, including chum, pink, chinook, and coho salmon, surf smelt, Pacific herring, and northern anchovy (Simenstad et al. 1991). We observed surf smelt Hypomesus pretiosus, juvenile salmon Oncorhynchus sp., gadids, cabezon Scorpaenichthys marmoratus, and other rockfish species in the drift vegetation habitat during this study, indicating that other commercial and sport species use this habitat.

The drift vegetation habitat and its seasonal effects would appear to be important considerations for ecologists and managers of the nearshore environment. Perturbations such as oil spills, upland and nearshore development, and logging have been documented and hypothesized to affect components of the drift vegetation habitat: detrimental effects might then flow on to important fish species. Fucus sp. and Nereocystis luetkeana, dominant features of north Puget Sound drift vegetation habitat, are sensitive to oil and dispersant and may suffer long term reproductive losses when exposed to either (Stekoll et al. 1993, Thom et al. 1993). Spills that impact nearshore areas where Fucus sp. and $N$. luetkeana grow may subsequently affect drift vegetation production. Many of the dominant epiphytic and planktonic organisms, as well as larval and juvenile fish found in the drift vegetation habitat, are also extremely sensitive to both crude oil and dispersant (Rosenthal \& Alderdice 1976, Wilson 1977, Hicks \& Coull 1983, Corell 1989). Finally, the physical forces that create drift vegetation habitat also accumulate oil and other debris. Effects of oil spills on drift vegetation habitat and use are to date unknown but very important for future study.

Upland human activities may impact nearshore vegetated habitats (Shaffer \& Parks 1994). If severe enough, these activities may result in shifts in or loss of nearshore intertidal and subtidal habitats that can in turn affect the drift vegetation habitat. For example, ulvoid drift algal mats, a growing feature of Washington estuaries, are created from nutrient enrichment associated with sewer and urban creek outfalls located in areas with poor water circulation. The mats are considered indicators of nutrient loading and may have negative impacts on nearshore invertebrate and fish species, as well as other vegetated habitats such as eelgrass beds (Hull 1987, Wright 1989, Sogard \& Able 1991, Isaksson et al. 1994). Impacts of upland activities on drift vegetation habitat use in Washington waters ąre unknown.

The drift vegetation habitat in waters of the San Juan Archipelago is temporally and spatially complex and provides habitat to juvenile Sebastes diploproa during summer and fall months. These preliminary results indicate that the trophic functions of this habitat may shift with time. Dependence on this habitat for both refuge and food by juvenile $S$, diploproa, use by other sport and commercial species of fish, and rapidly changing nearshore environments of Washington indicate that the drift vegetation habitat should receive further attention for nearshore management and study in the future.

Acknowledgements. The authors are grateful to Ms Betty Bookheim for high quality, dedicated field assistance. Mr Jeff Cordell provided invaluable advice and taxonomic verification. Mr Charles Simenstad and Ms Katie Swanson provided FORTRAN programs and support critical for data analysis. Drs Loveday Conquest and Jan Spyridakis offered useful advise and guidance. Ms Shirley Pinneo, Jackie Coleman, and Mr Dale Gombert proviced tireless computer support. Messrs Kurt Fresh and Wayne Palsson, and Dr Jack Tagart offered insightful manuscript review. Funding for this work was provided through the Dingell-Johnson/Wallop Breaux Federal Aid in Sport Fish Restoration Act, administered by the U.S. Fish and Wildlife Service, contract F-102-R.

\section{LITERATURE CITED}

Carr MH (1989) Effects of macroalgal assemblages on the recruitment of temperate zone reef fishes. $J$ exp mar Biol Ecol 126:59-76

Corell A (ed) (1989) Using oil spill dispersant on the sea National Academy Press, Washington, DC

Foster MS, Schiel DR (1.985) The ecology of giant kelp forests in California: a community profile. USFWS Biol Rep 85(7.2)

Franks PS (1992) Sink or swim: accumulation of biomass at fronts. Mar Ecol Prog Ser 82:1-12

Gorelova TA, Fedoryako BI (1986) Topic and trophic relationships of fishes associated with drifting Sargassum vegetation. J Ichthyol 26(2):63-72

Haldorson L, Richards LJ (1986) Post larval copper rockfish in Strait of Georgia: habitat use, feeding, and growth in the first year. Proc Int Rockfish Symp, Anchorage, p 129-141 
Harrold CH, Lisin S (1989) Radio tracking rafts of giant kelp: local production and regional transport. J exp mar Bio Ecol $130: 237-252$

Heck KL, Thoman TA (1981) Experiments on predator-prey interactions in vegetated aquatic habitats. J exp mar Biol Ecol 53:125-134

Hicks GR (1986) Distribution and behavior of meiofaunal copepods inside and outside eelgrass beds. Mar Ecol Prog Ser 31:159-170

Hicks GRF, Coull BC (1983) The ecology of marine meiobenthic harpacticoid copepods. Oceanogr mar Biol A Rev 21: $67-175$

Hull SC (1987) Macroalgal mats and species abundance: a field experiment. Estuar coast Shelf Sci 25:519-532

Isaksson I, Pihl L, van Montfrans J (1994) Eutrophicationrelated changes in macrovegetation and foraging of young cod (Gadus marhua L.): a mesocosm experiment. $J$ exp mar Biol Ecol 177:203-217

Johnson DL, Richardson PL (1977) On the wind-induced sinking of Sargassum. J exp mar Biol Ecol 28:255-267

Kingsford MJ (1992) Drift algae and small fish in coastal waters of northeastern New Zealand. Mar Ecol Prog Ser $80: 41-52$

Kingsford MJ, Choat JH (1985) The fauna associated with drift algae captured with a plankton mesh purse seine net. Limnol Oceanogr 30(3):618-630

Kulczycki GR, Virnstein RW, Nelson WG (1981) The relationship between fish abundance and algal biomass in a seagrass-drift algae community. Estuar coast Shelf Sci 12: 341-347

Lenanton RCJ (1982) Alternative non-estuarine nursery habitats for some commercially and recreational important fish species of southeastern Australia. Aust $J$ mar Freshwat Res 33:881-900

Lenanton RCJ, Caputi N (1989) The roles of food supply and shelter in the relationship between fishes, in particular Cnidoglanis macrocephalus (Valenciennes) and detached macrophytes in the surf zone of sandy beaches. $J$ exp mar Biol Ecol 128:165-176

Love MS, Carr MH, Haldorson LJ (1991) The ecology of substrate associated juveniles of the genus Sebastes sp. Environ Biol Fish 30:225-243

Manly BFJ, Miller P, Cook LM (1972) Analysis of a selective predation experiment. Am Nat 10:719-736

Mitchell CT, Hunter JR (1970) Fishes associated with drifting kelp Macrocystis pyrifera, off the coast of southern California and northern Baja California. Calif Fish Game 56 (4):288-297

This article was submitted to the editor
Pielou EC (1975) Ecological models on an environmental gradient. In: Gupta RP (ed) Applied statistics. North-Holland Publ Co

Price HL (1989) Swimming behavior of krill in response to algal patches: a mesocosm study. Limnol Oceanogr 34(4):649-659

Robertson AI, Lenanton RCJ (1984) Fish community structure and food chain dynamics in the surf zone of sandy beaches: the role of detached macrophyte detritus. J exp mar Biol Ecol 84:265-283

Rosenthal H, Alderdice DF (1976) Sublethal effects of environmental stressors, natural and pollutional, on marine fish eggs and larvae. J Fish Res Bd Can 33:2047

Savino JF, Stein RA (1989) Behavior of fish predators and their prey: habitat choice between open water and dense vegetation. Environ Biol Fish 24(4):287-293

Shaffer JA, Parks DS (1994) Seasonal changes in and observed landslide impacts to a Puget Sound bull kelp (Nereocystis luetkeana) forest. Botanica mar 37:315-323

Shanks A. (1988) Further support for the hypothesis that internal waves can cause shoreward transport of larval invertebrates and fish. Fish Bull US 86(4):703-714

Simenstad CA, Kinney W, Miller BS (1980) Epibenthic zooplankton assemblages at selected sites along the Strait of Juan de Fuca. NOAA technical memorandum, ERL MESA-46. School of Fisheries, University of Washington, FRI-UW 8002, Seattle

Simenstad CA, Tanner CD, Thom RM, Conquest LL (1991) Estuarine habitat assessment protocol. U.S. EPA 910/9-91037

Sogard SM, Able KW (1991) A comparison of eelgrass, sea lettuce, macroalgae, and marsh creeks as habitats for epibenthic fishes and decapods. Estuar coast Shelf Sci 33: $501-519$

Stekoll MS, Deysher L, Guo Z (1993) Coast habitat injury assessment: intertidal algal communities. Exxon Valdez Oil Spill Symposium, 2-5 February 1993. Sponsored by the University of Alaska Sea Grant, Anchorage

Thom RM, Antrim LD, Gardiner WW, Cullinan VI, Shreffler DK, Bienert RW (1993) Effects of petroleum products on bull kelp (Nereocystis luetkeana P\&R). Report to Washington State Department of Natural Resources, Olympia

Wilson KW (1977) Acute toxicity of oil dispersants to marine fish larvae. Mar Biol 40:65-74

Wright JM (1989) Detached chlorophytes as nursery areas for fish in Sulaibikhat Bay, Kuwait. Estuar coastal Shelf Sci 28 : $185-193$

Zar JH (1984) Biostatistical analysis. Prentice-Hall, Inc, Englewood Cliffs, NJ

Manuscript first received: October 19, 1994

Revised version accepted: April 13, 1995 